\title{
Differential Influx of Natural Plant Growth Regulators during Embryogeny in the Recalcitrant Seeds of Syzygium cumini (L) Skeels
}

\begin{abstract}
Background: The hormonal up-regulation and down-regulation in recalcitrant seeds, on the other hand, has received little research. We tested fou plant growth regulators from distinct families of phytohormones at the same time to better understand their differential input from maternal tissues to growing Syzygium cumini seeds.

Methods: During April-June 2020, seeds were collected in their native habitats in the Western Ghats. Seeds were chosen at random from each treatment. The embryonic tissues of seeds were chopped up and frozen for LC-MS/MS hormonal profiling.

Result: Except for ABA, the dynamics of key plant hormones in this recalcitrant seed were identical to that of desiccation-tolerant orthodox seeds. When compared to other conventional seeds, SA was shown to accumulate at an unusually high level in mature embryonic tissues, demonstrating the highly hydrated seed's defense mechanism against fungal attack following seed shedding.
\end{abstract}

Key words: Days after anthesis, Embryogeny, LC-MS/MS, Plant growth regulators, Syzygium cumini.

\section{INTRODUCTION}

Syzygium cumini (L.) Skeels, often known as Jamun, Malabar plum, or Indian blackberry, is an evergreen indigenous arborescent tree belonging to the Myrtaceae family (Soh and Parnell, 2015). It's native to Nepal, Sri Lanka, Pakistan and Indonesia (IUCN, 2019) and its edible fruits are commercially used (Soh, 2017). It also has pharmacological characteristics (Swami and Kalse, 2020). The species has been designated as endangered because of issues with natural regeneration and the seeds have been described as recalcitrant, with embryos losing viability extremely soon, according to Nair et al. (2020).

Plant growth regulators (PGRs) are important throughout several stages of embryogenesis, including histodifferentiation, reserve storage and embryo drying. These PGRs have been reported to be up-regulated or down-regulated at various phases of embryogenesis in orthodox seeds (Farrant et al., 1993). Despite the absence of embryo drying, such information is not available in the desiccation-intolerant recalcitrant seeds. The very recalcitrant seed of $S$. cumini was chosen for this study to better understand the dynamics of PGRs throughout embryogenesis. It also looked at the GA/ABA antagonistic relationship in this recalcitrant seed.

\section{MATERIALS AND METHODS Collections}

Jamun seeds were collected from natural stands in the Western Ghats, at an elevation of 150 meters above sea level in the southern Western Ghats (Latitude- $8^{\circ} 45^{\prime}$ and $8^{\circ} 47^{\prime} \mathrm{N}$; Longitude $-77^{\circ} 1^{\prime}$ and $\left.77^{\circ} 4^{\prime} \mathrm{E}\right)$. During April-June
Department of Botany, Govt College for Women, Thiruvananthapuram-605 014, Kerala, India.

Corresponding Author: Parvathy S. Nair, Department of Botany, Govt College for Women, Thiruvananthapuram-605 014, Kerala, India. Email: snairparvathy92@gmail.com

How to cite this article: Parvathy S. Nair, K.G. Ajith Kumar, G.P. Gayatri and Ajayakumar (2022). Differential Influx of Natural Plant Growth Regulators during Embryogney in the Recalcitrant Seeds of Syzygium cumini (L) Skeels. Indian Journal of Agricultural Research. DOI: 10.18805/IJARe.A-5904.

Submitted: 26-08-2021 Accepted: 02-12-2021 Online: 15-01-2022

2020, Greller et al. (1999). The coldest and highest temperatures were $100.4^{\circ} \mathrm{F}$ and $55.4^{\circ} \mathrm{F}$, respectively; the relative humidity varied from 48 to 97 per cent and the maximum rainfall was $2492.04 \mathrm{~mm}$ (India Meteorological Department, 2020).

The flowers were tagged at anthesis in April and the fruits at maturity stages; early embryogeny (40 days after anthesis), mid-embryogeny (70 days after anthesis) and late embryogeny (95 days after anthesis) seeds were collected and the malformed/infected seeds were discarded. The seeds were surface sterilized with $1 \%$ sodium hypochlorite for 10 minutes Nakagawara et al. (1998). A hundred seeds from each treatment were chosen at random and the seed coat was removed. For hormonal profiling, the embryonic tissues of a hundred seeds were chopped up and frozen. The extraction of various plant growth regulators was done according to the procedure of Pan et al. (2008). 


\section{Statistical analysis}

Data presented correspond to means \pm standard error. Analysis of variance, DMRT were carried out with SPSS, version 11.5 software. All treatments consisted of three replicates.

\section{RESULTS AND DISCUSSION}

PGRs belonging to different classes of phytohormones were assayed simultaneously in the embryonic tissues of S.cumini and the results are summarized in Table (1). Significant variation $(p<0.01)$ was observed in the levels of hormones during embryogeny and certain hormones were found to be up-regulated or down-regulated at different stages of embryogeny in this recalcitrant seed.

\section{Auxins}

The two natural forms of auxins; IAA and IBA were assayed in the embryonic tissues during the embryogeny and IAA was found to be the predominant form of auxins in this recalcitrant seed. The young embryonic tissue
(Chromatogram 1) had an elevated IAA content (51.53 ng $\mathrm{g}^{-1} \mathrm{fw}$ ) probably supplied by the maternal tissues and it got accumulated (67.82 $\mathrm{ng} \mathrm{g}^{-1} \mathrm{fw}$ ) in the embryonic tissues of mid-embryogeny (Chromatogram 3 ) and then declined to $40.71 \mathrm{ng} \mathrm{g}^{-1} \mathrm{fw}$ in the late embryogeny (Chromatogram 5). IBA also showed a characteristic curve like IAA but with lower levels. This indicates the significance of these auxins during embryo differentiation in this recalcitrant seed. The significance of elevated levels of IAA and IBA in the histodifferentiation process has already been reported (Valpuesta et al., 1989) and is also essential for the development of bipolar symmetry of the embryo (Wijers and Jurgens, 2005). The subsequent decline of IAA and IBA in the late embryogeny stage indicates that these auxins do not appear to be involved in reserve accumulation in the cotyledonary tissues. The dynamics of both IAA and IBA during embryogeny were strikingly similar to that reported for other desiccation-sensitive recalcitrant species (Farrant et al., 1993) and desiccation-tolerant orthodox seeds (Pharis and King, 1985; Reinecke and Bandurski, 1987).

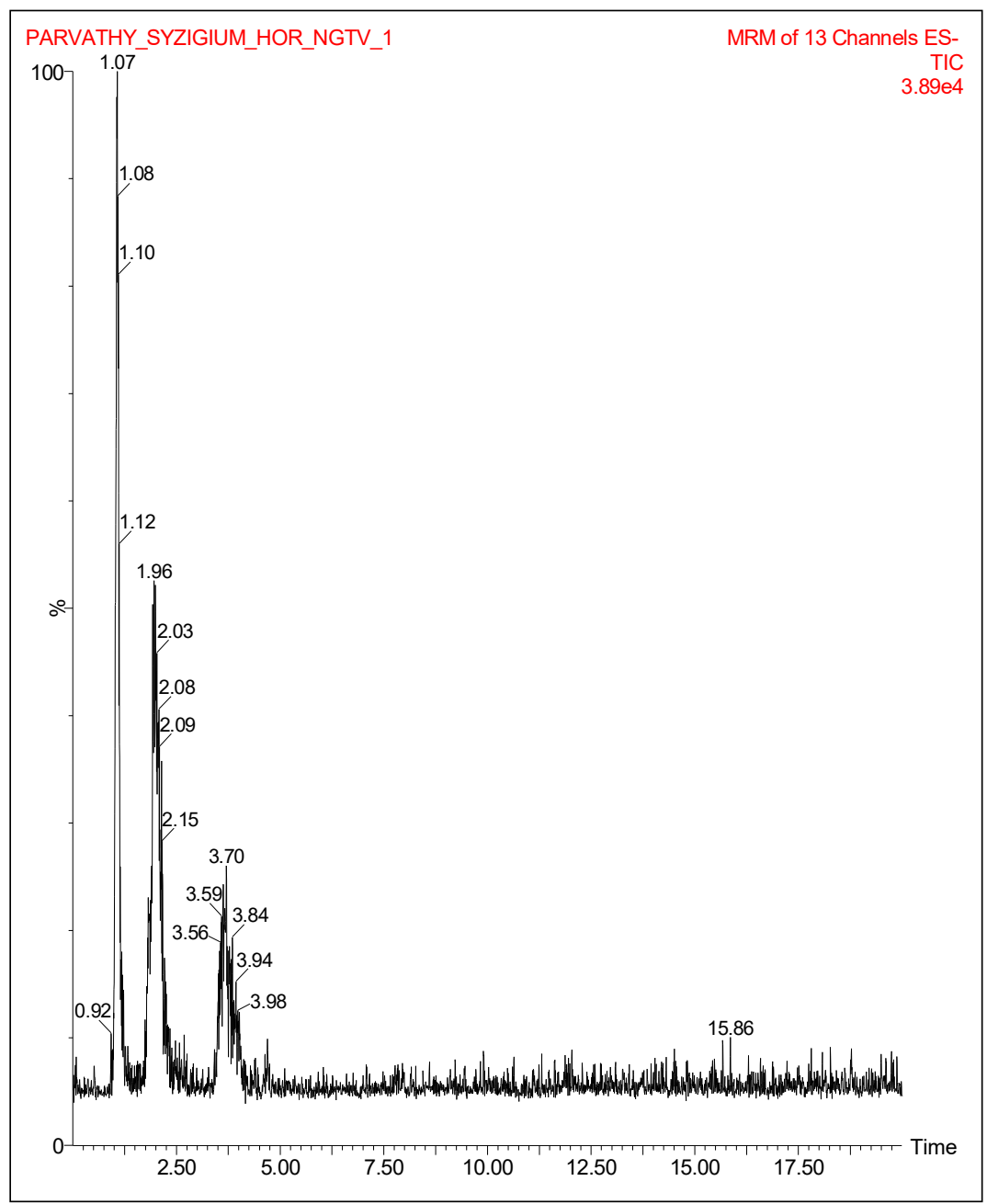

Chromatogram 1: Simultaneous analysis of hormones in the embryonic tissues of $S$. cumini during early embryogeny. In negative mode (ES-) - Salicylic acid, IAA, IBA, JA, benzene adenine, ABA, GA-7, GA-4, GA-3, epibrassinolide. 


\section{Gibberellins}

Three principal forms of gibberellins; $\mathrm{GA}_{3}, \mathrm{GA}_{4}$ and $\mathrm{GA}_{7}$ were assayed during the embryogeny and it was found that $\mathrm{GA}_{4}$ was the only predominant form during all stages of embryo development whereas $\mathrm{GA}_{3}$ and $\mathrm{GA}_{7}$ were found in insignificant levels. However, $\mathrm{GA}_{3}$ is reported to be the predominant form of gibberellins in many orthodox and recalcitrant species (Farrant et al., 1993; Romero-Rodriguez et al., 2018). The young embryo had a lower level of $\mathrm{GA}_{4}$ (29.7 $\mathrm{ng} \mathrm{g}^{-1} \mathrm{fw}$ ) during early embryogeny (Chromatogram 1) but a sharp rise could be observed in the embryogenic tissue (172.86 $\mathrm{ng} \mathrm{g}^{-1} \mathrm{fw}$ ) during mid-embryogeny (Chromatogram 3) and then a sharp decline in the late embryogeny (65.22 ng $\mathrm{g}^{-1} \mathrm{fw}$ ) (Chromatogram 5). The faster influx of $\mathrm{GA}_{4}$ from the maternal tissues to the developing embryos indicates the significance of the histodifferentiation process. The dynamics of $\mathrm{GA}_{4}$ were very similar to that of IAA and were found to be a common character shared by both orthodox and recalcitrant seeds (Farrant et al., 1993). The embryonic tissue of mature recalcitrant seed maintained a relatively high level of $\mathrm{GA}_{4}$ compared to orthodox seeds which are considered as an adaptation in recalcitrant embryos to antagonize ABA and to carry out quicker germination without any dormancy as seen in orthodox seeds (RomeroRodriguez et al., 2018; Vishal and Kumar, 2018; Zhang, 2007; Farrant et al., 1993, Musatenko et al., 1995).

\section{Abscisic acid}

$A B A$ is reported to be an important plant growth regulator in preventing premature germination and desiccation tolerance acquisition in desiccation-tolerant orthodox seeds (AliRachedi et al., 2004). The young embryonic tissue (Chromatogram 1)of this recalcitrant seed had a lower ABA content (23.04 $\left.\mathrm{ng} \mathrm{g}^{-1} \mathrm{fw}\right)$ that got accumulated significantly in the embryonic tissues (88.95 $\mathrm{ng} \mathrm{g}^{-1} \mathrm{fw}$ ) during midembryogeny (Chromatogram 3 ) and then declined to 51.77 $\mathrm{ngg}^{-1} \mathrm{fw}$ in the mature embryonic tissues (Chromatogram 5) during late embryogeny. The initial rapid accumulation of

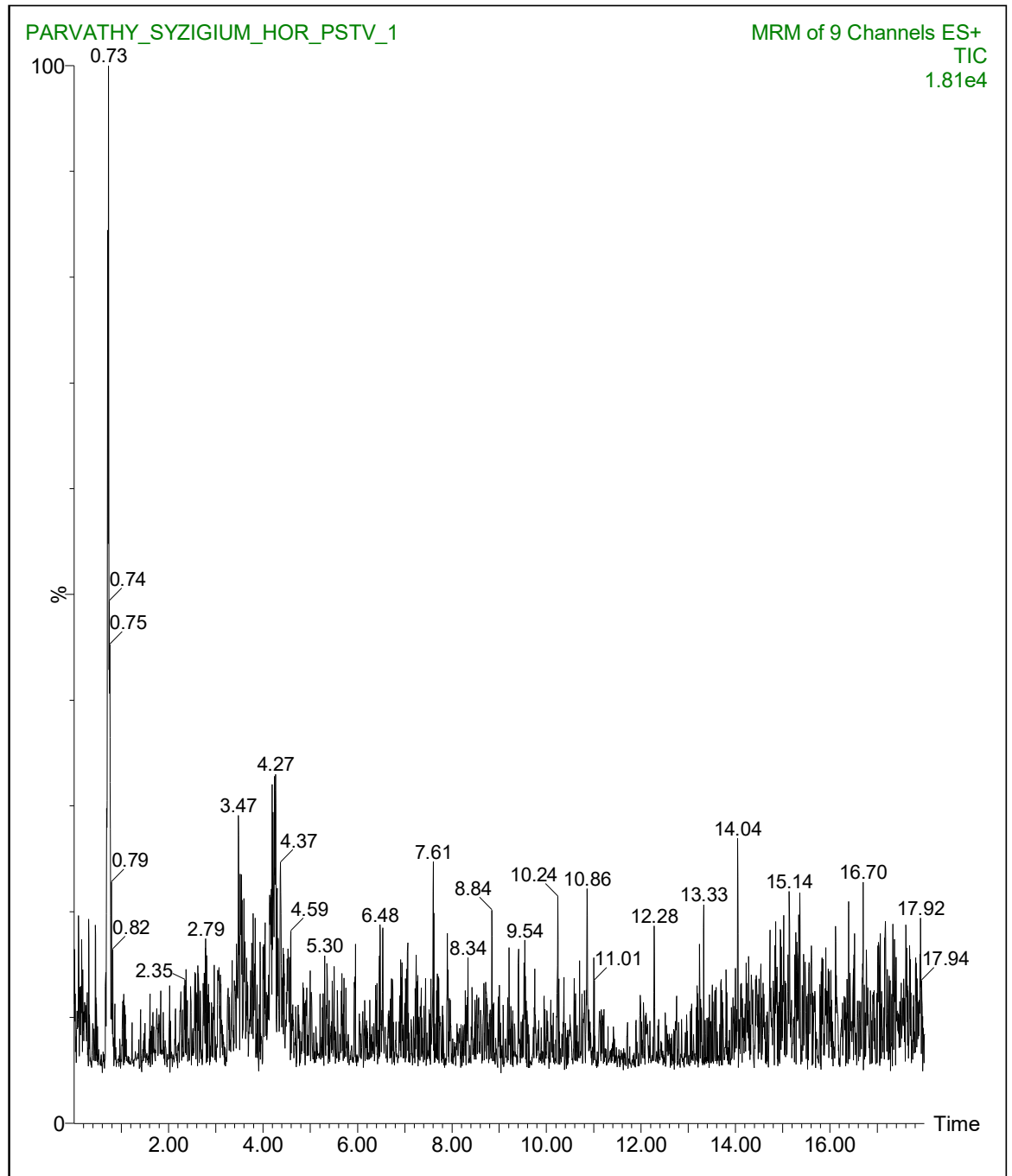

Chromatogram 2: Simultaneous analysis of hormones in the embryonic tissues of S. cumini during early embryogeny. In positive mode (ES+) - ACC, Cis-jasmonate, zeatin, methyl jasmonate and trans zeatin riboside. 
Differential Influx of Natural Plant Growth Regulators during Embryogney in the Recalcitrant Seeds of Syzygium cumini (L) Skeels

$A B A$ in the mid embryogeny stage is linked with the mechanism shown by recalcitrant seeds to prevent precocious germination. However, in orthodox seeds, ABA accumulation is observed in association with the onset of embryo drying phase only and is found in insignificant levels in other stages (Farrant et al. 1993). The decline in ABA content to $51.77 \mathrm{ng} \mathrm{g}^{-1} \mathrm{fw}$ and the elevated level of $\mathrm{GA}_{4}$ in the embryonic tissues of mature seeds facilitate quicker germination in this recalcitrant seed (Farrant et al., 1993; Romero-Rodriguez et al., 2018, Gayatri et al., 2021).

\section{Cytokinins}

The different forms of cytokinins; $B A, t Z$ and $t Z R$ were assayed in the embryonic tissues during embryogeny and found that BA was the predominant form found in elevated levels in all stages of embryo development. The large influx of this PGR from the maternal tissues to the young embryo (193.23ng g ${ }^{-1} \mathrm{fw}$ ) was observed during the histodifferentiation stage as it is required for rapid cell divisions, embryo and endosperm formation and endosperm utilization (van Staden et al., 1982; Lorenzi et al., 1988). This level of BA was maintained till the mid-embryonic stage (Chromatogram 3) (206.01 $\left.\mathrm{ng} \mathrm{g}^{-1} \mathrm{fw}\right)$ and it was followed by a decline (128ng g${ }^{1} \mathrm{fw}$ ) after the reserve food accumulation stage (Chromatogram 5). The same trend has been reported for other desiccation-sensitive species (Farrant et al., 1993). Keeping a relatively high level of BA in the mature embryonic tissue at the seed shedding stage is a requirement in this recalcitrant seed to carry out faster germination without any delay (Romero-Rodriguez et al., 2018) and also to antagonize the ABA during germination (Wang et al., 2011). $\mathrm{tZ}$, the next dominant cytokinins, showed lower levels in the histodifferentiation stage (Chromatogram 2) (6.9 $\mathrm{ng} \mathrm{g}^{-1} \mathrm{fw}$ ) and mid-embryogeny (Chromatogram 4) (7.32 $\mathrm{ng} \mathrm{g}^{-1} \mathrm{fw}$ ) but elevated $\left(30.75 \mathrm{ng} \mathrm{g}^{-1} \mathrm{fw}\right)$ after the completion of the reserve accumulation stage (Chromatogram 6). However, tZR, a

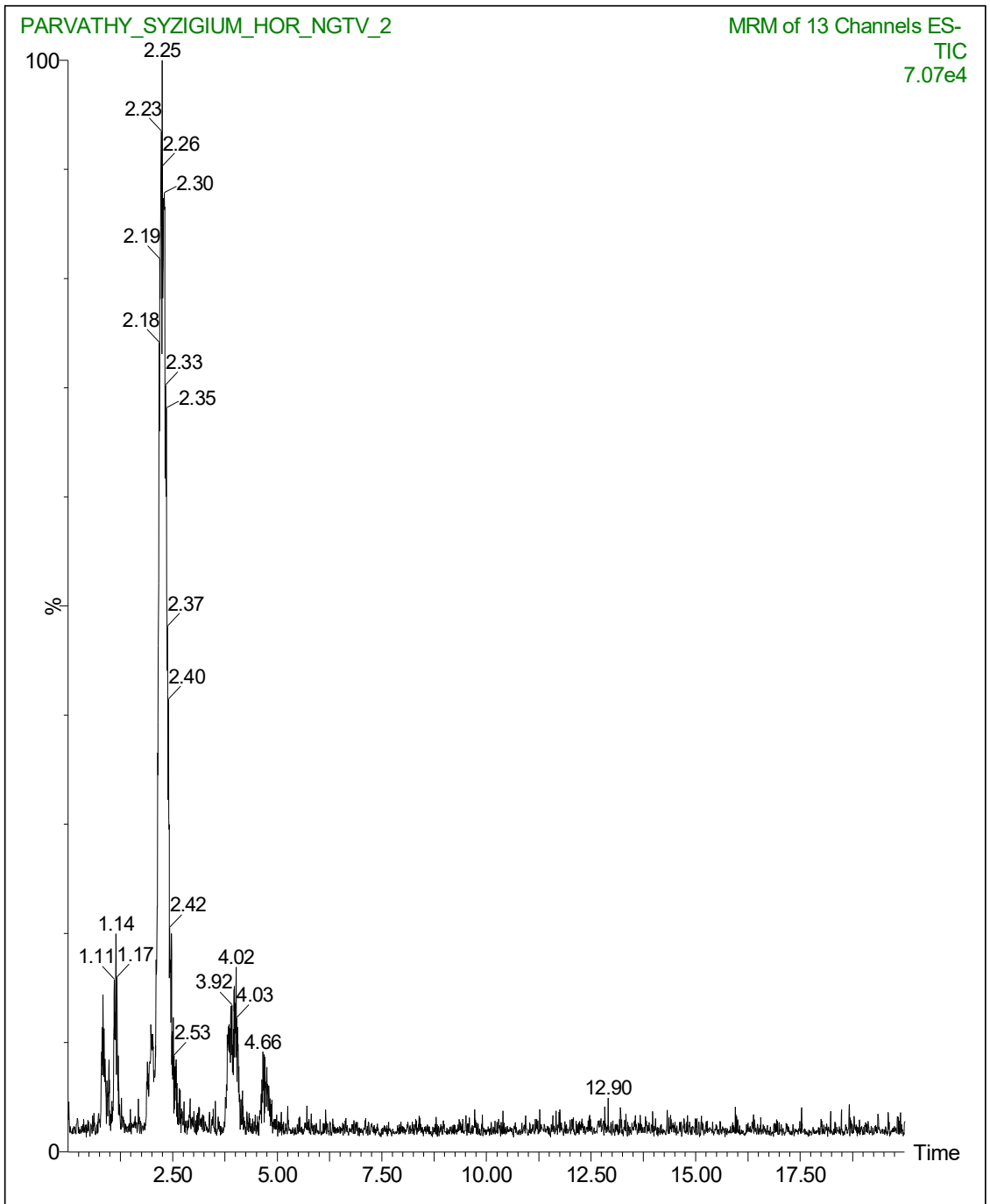

Chromatogram 3: Simultaneous analysis of hormones in the embryonic tissues of $S$. cumini during mid-embryogeny. In negative mode (ES-): Salicylic acid, IAA, IBA, JA, benzene adenine, ABA, GA-7, GA-4, GA-3, epibrassinolide. 
Differential Influx of Natural Plant Growth Regulators during Embryogney in the Recalcitrant Seeds of Syzygium cumini (L) Skeels

Table 1: Changes in plant growth regulators during different stages of embryogeny in S. cumini.

\begin{tabular}{|c|c|c|c|c|c|}
\hline \multirow{2}{*}{$\begin{array}{l}\text { Plant growth regulators } \\
\text { (ng g-1 fwt) }\end{array}$} & \multicolumn{3}{|c|}{ Stages of embryogeny } & \multirow{2}{*}{$\begin{array}{l}\text { Grand } \\
\text { mean }\end{array}$} & \multirow{2}{*}{$\begin{array}{l}\text { Standard } \\
\text { deviation }\end{array}$} \\
\hline & Early (40 DAA) & Mid (70 DAA) & Late (95 DAA) & & \\
\hline 3-Indole acetic acid (IAA) & $51.53 \pm 3.81^{a}$ & $67.82 \pm 0.82^{\mathrm{b}}$ & $40.71 \pm 0.5^{c}$ & 53.35 & 12.45 \\
\hline 3-Indole butyric acid (IBA) & $8.88 \pm 0.55^{\mathrm{a}}$ & $17.28 \pm 0.34^{b}$ & $5.04 \pm 0.7^{a}$ & 10.41 & 5.63 \\
\hline Gibberellic acid 7 (GA7) & ) & $0.02 \pm 0.04^{a}$ & $0.04 \pm 0.002^{\mathrm{a}}$ & 0.031 & 0.01 \\
\hline Gibberellic acid 4 (GA4) & $29.7 \pm 2.92^{\mathrm{a}}$ & $172.86 \pm 3.97^{b}$ & $65.22 \pm 5.45^{\mathrm{c}}$ & 89.26 & 66.83 \\
\hline Gibberellic acid 3 (GA3) & $0.27 \pm 0.011^{a}$ & $2.74 \pm 0.18^{a}$ & $0.28 \pm 0.01^{a}$ & 1.1 & 1.27 \\
\hline Zeatin trans isomer & $6.9 \pm 0.41^{a}$ & $7.32 \pm 0.56^{a}$ & $30.75 \pm 0.17^{b}$ & 14.99 & 12.21 \\
\hline Trans zeatin riboside & $8.84 \pm 0.17^{a}$ & $17.88 \pm 3.15^{b}$ & $5.09 \pm 0.16^{c}$ & 10.6 & 6.21 \\
\hline Benzyl aminopurine & $193.23 \pm 8.48^{a}$ & $206.01 \pm 6.54^{b}$ & $128.46 \pm 2.9^{c}$ & 175.9 & 37.85 \\
\hline Abscisic acid (ABA) & $23.04 \pm 0.016^{a}$ & $88.95 \pm 1.06^{b}$ & $51.77 \pm 0.52^{c}$ & 54.59 & 29.56 \\
\hline Salicylic acid (SA) & $11865.57 \pm 106.98^{a}$ & $5637.94 \pm 92.42^{\mathrm{b}}$ & $18997.85 \pm 143.12^{\mathrm{c}}$ & 12167.12 & 5980.6 \\
\hline Jasmonic acid (JA) & $0.06 \pm 0.005^{\mathrm{a}}$ & $0.1 \pm 0.006^{\mathrm{a}}$ & $0.12 \pm 0.006^{a}$ & 0.096 & 0.02 \\
\hline Methyl jasmonate & $1.24 \pm 0.03^{a}$ & $3.55 \pm 0.18^{a}$ & $4.12 \pm 0.17^{a}$ & 2.97 & 1.37 \\
\hline Cis-jasmone & $26.31 \pm 7.45^{\mathrm{a}}$ & $46.45 \pm 0.54^{b}$ & $148.48 \pm 2.02^{c}$ & 73.75 & 58.79 \\
\hline Epibrasinolide (24 epiBL) & $19 \pm 1.72^{a}$ & $20.02 \pm 0.95^{a}$ & $13.65 \pm 0.91^{c}$ & 17.55 & 3.35 \\
\hline $\mathrm{ACC}$ & $0.48 \pm 0.06^{\mathrm{a}}$ & $0.56 \pm 0.38^{c}$ & $1.12 \pm 0.9^{b}$ & 0.72 & 0.31 \\
\hline
\end{tabular}

Values are averages of four replications with standard error; Dynamics of PGRs in seeds of Syzygium cumini during embryogeny. Mean followed by the same letter in the column are not statistically different from each other by Duncan test (ANOVA).

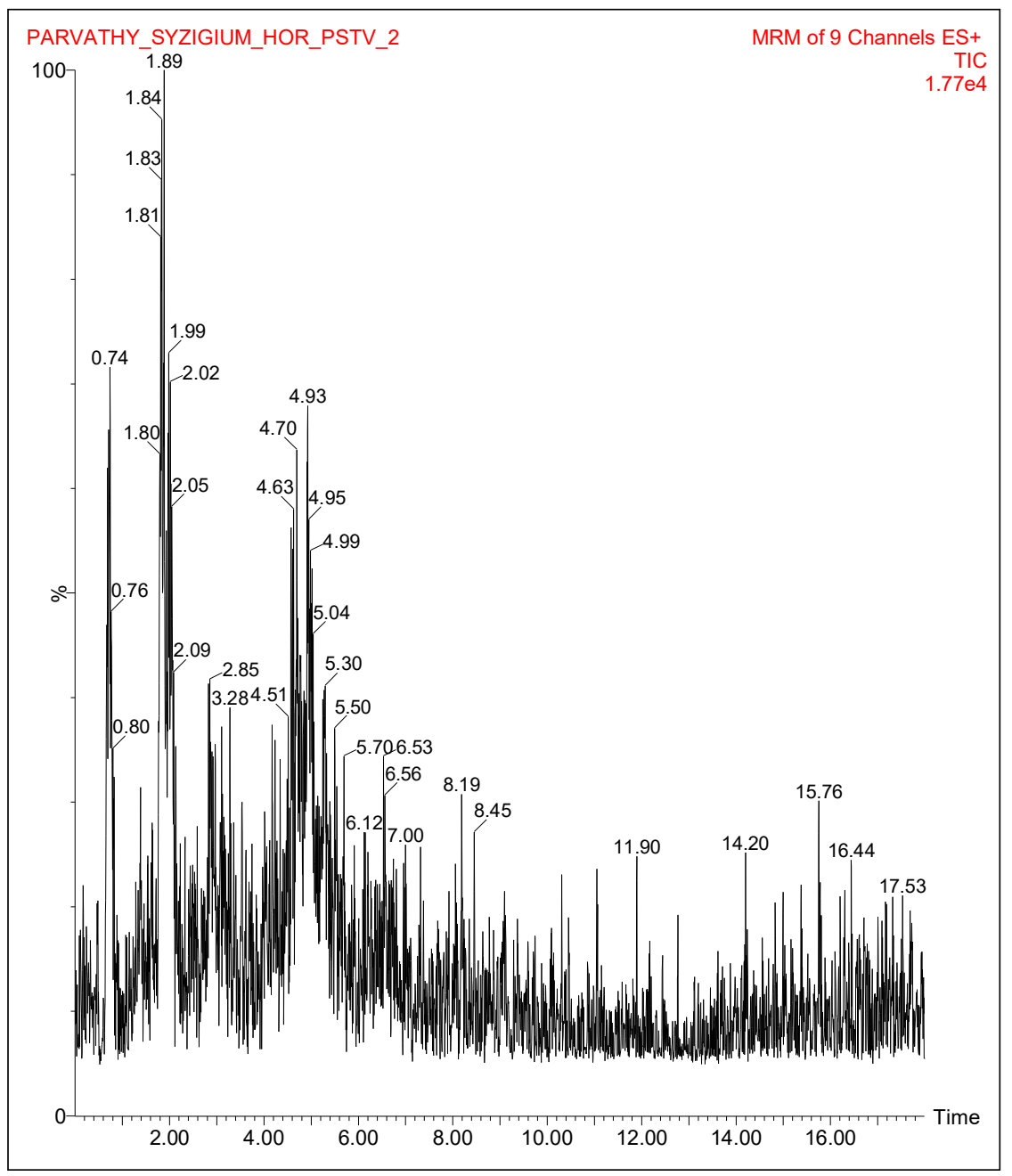

Chromatogram 4: Simultaneous analysis of hormones in the embryonic tissues of S. cumini during mid-embryogeny. In positive mode (ES+) - ACC, Cis-jasmonate, zeatin, methyl jasmonate and trans zeatin riboside. 
predominant form of cytokinins in other orthodox and recalcitrant seeds, was found in lower quantities during embryogeny in this seed but showed similar dynamics as that of BA.

\section{Salicylic acid}

SA is a phenolic PGR known to influence seed development and seed germination processes (Mariana Rivas-San Vicente and Javier Plasencia, 2011). However, reports are contradictory suggesting that it can either inhibit or enhance seed germination (Rajjou et al., 2006; Xie et al., 2007; Ana Alonso-Ramirez et al., 2009). In the present study, this PGR was found in exceptionally greater quantities, ranging from $5.63 \mu \mathrm{g} \mathrm{g}^{-1} \mathrm{fw}$ to $19 \mu \mathrm{g} \mathrm{g}^{-1} \mathrm{fw}$, in the embryonic tissues during embryogeny. This level of SA in seeds is higher compared to that reported in other species. In the model species, Arabidopsis thaliana, the basal level of SA in the leaves ranged from $0.25 \mu \mathrm{g} \mathrm{g}^{-1} \mathrm{fw}$ to $1 \mu^{-1} \mathrm{~g} \mathrm{~g}^{-1} \mathrm{fw}$ (Peter et al. 2005). The initial huge influx of SA from the maternal tissues (11.86 $\mu \mathrm{g} \mathrm{g}^{-1} \mathrm{fw}$ ) indicates that it might be essential for the histodifferentiation process. There was a decline in SA towards mid-embryogeny (Chromatogram 3) (5.63 $\left.\mu \mathrm{g} \mathrm{g}^{-1} \mathrm{fw}\right)$ and then a sharp rise in late embryogeny (Chromatogram 5) $\left(19 \mu \mathrm{g} \mathrm{g}^{-1} \mathrm{fw}\right)$. The elevated level of this hormone is normally associated with stressful conditions (Alonso-Ramirez et al. 2009) but the precise role of this hormone during embryogeny is unknown. However, there are reports of crosstalk between SA with GAs and ABA during germination (Rajjou et al. 2006; Ana Alonso-Ramirez et al., 2009). Further work is needed to solve this problem.

\section{Jasmonates}

Jasmonates are a class of PGRs influencing many developmental processes such as seed germination, root growth, embryo development, fruit ripening and gravitropism (Browse and Howe, 2008; Reinbothe et al., 2009; Gfeller et al., 2010). Three forms of jasmonates; JA, meJ and CisJ were assayed in the embryonic tissues during embryogeny

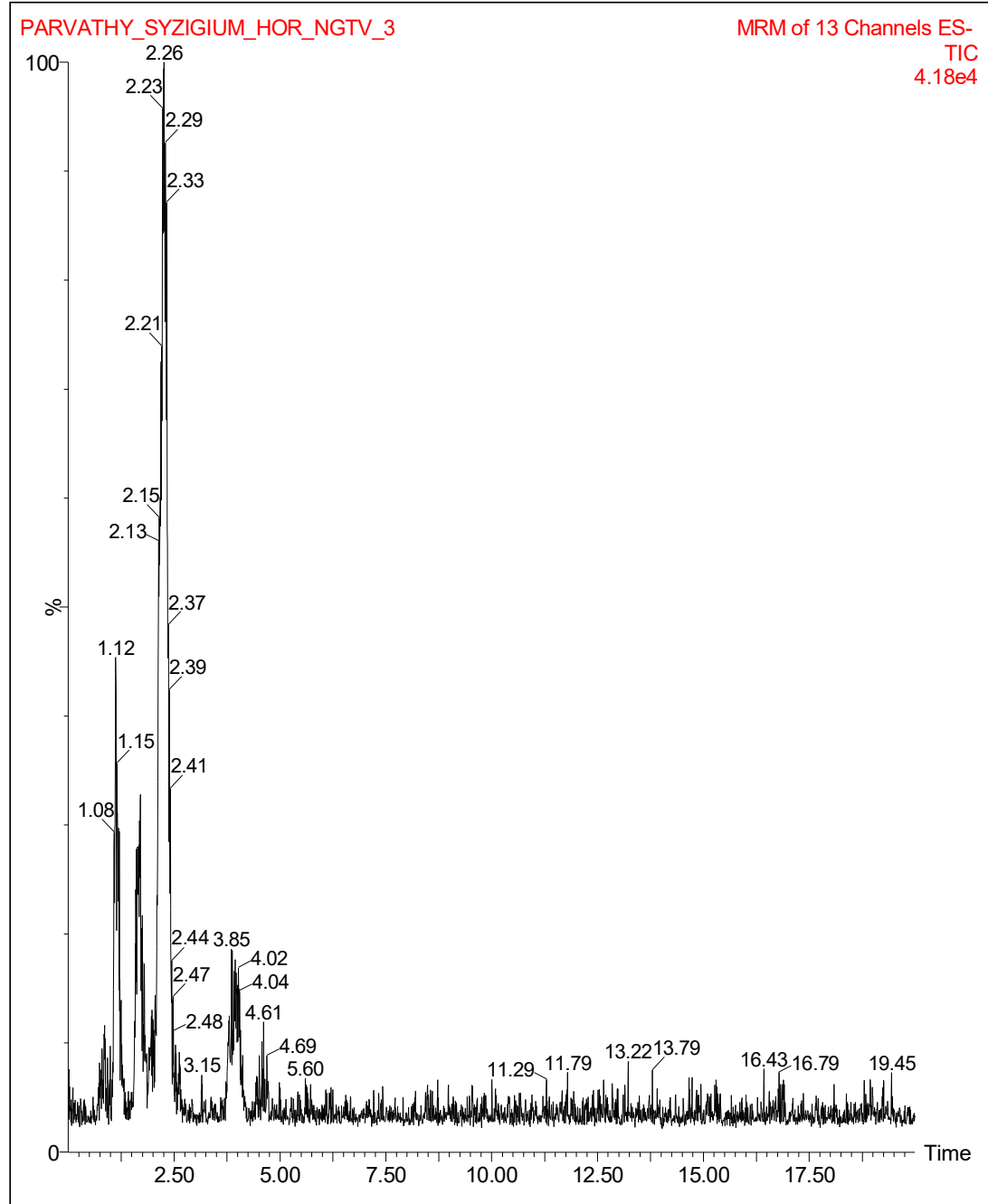

Chromatogram 5: Simultaneous analysis of hormones in the embryonic tissues of $S$. cumini during late embryogeny. In negative mode (ES-) - Salicylic acid, IAA, IBA, JA, benzene adenine, ABA, GA-7, GA-4, GA-3, epibrassinolide. 


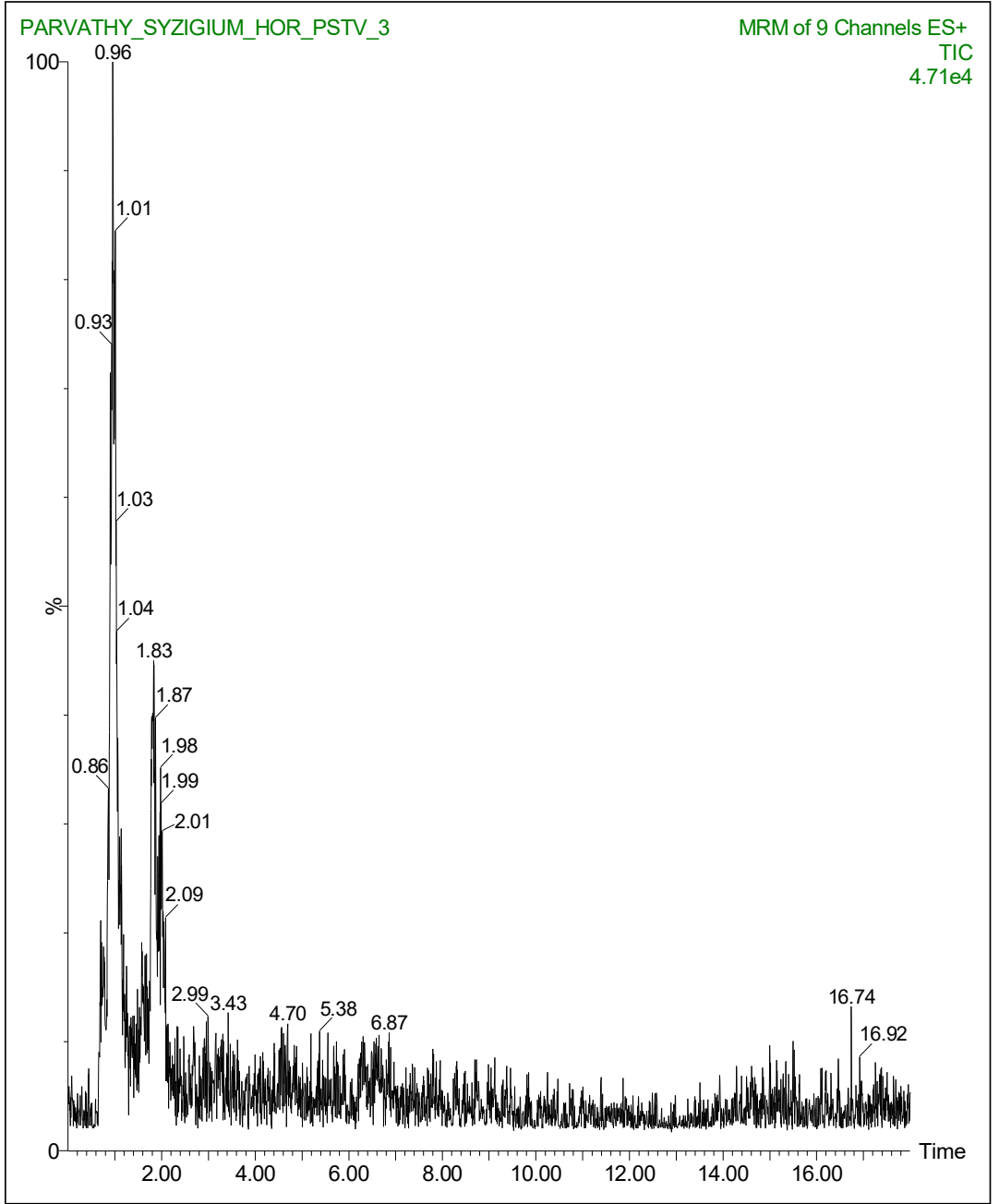

Chromatogram 6: Simultaneous analysis of hormones in the embryonic tissues of $S$. cumini during late embryogeny. In positive mode (ES+) - ACC, Cis-jasmonate, zeatin, methyl jasmonate and trans zeatin riboside.

and found that the predominant form of jasmonates was cisJ which was found to accumulate $\left(26.31 \mathrm{ng} \mathrm{g}^{-1} \mathrm{fw}\right.$ to 46.45 ng $\mathrm{g}^{-1} \mathrm{fw}$ ) during the histodifferentiation process (Chromatogram 2). However, a sharp rise was observed in the reserve food accumulation phase (Chromatogram 4) indicating a crucial role of this PGR in the developmental process that needs to be resolved. meJ and JA were found in insignificant levels in the embryonic tissues during embryogeny.

\section{Brassinosteroids}

Brassinosteroids are steroid PGRs involved in shoot growth, root growth, vascular differentiation and seed germination (Clouse and Sasse, 1998; Fukunda, 2004; Mussig, 2005). The predominant form of brassinosteroids, 24epi-BL was found in significant amounts in the embryonic tissues of all stages of embryogeny. It peaked during histodifferentiation (Chromatogram 1) and then declined in the reserve food accumulation stage (13.65 $\mathrm{ng} \mathrm{g}^{-1} \mathrm{fw}$ ). The results indicate that this steroid $P G R$ is equally essential for the development of the seed but its exact role is uncertain.

\section{CONCLUSION}

The desiccation-intolerant recalcitrant seeds of Syzygium cumini showed dynamics in PGRs during embryogeny. IAA, $\mathrm{GA}_{4}$ and $\mathrm{BA}$ were found to be the predominant forms in their respective classes. These PGRs were found in elevated levels in the histodifferentiation process and declined in the subsequent reserve food accumulation phase of this recalcitrant embryo development. IAA (40.71 $\left.\mathrm{ng} \mathrm{g}^{-1} \mathrm{fw}\right), \mathrm{GA}_{4}$ (65.22 $\left.\mathrm{ng} \mathrm{g}^{-1} \mathrm{fw}\right), \mathrm{BA}\left(128.46 \mathrm{ng} \mathrm{g}^{-1} \mathrm{fw}\right), \mathrm{ABA}\left(51.77 \mathrm{ng} \mathrm{g}^{-1} \mathrm{fw}\right)$, SA $\left(19 \mu \mathrm{g} \mathrm{g}^{-1} \mathrm{fw}\right)$ and cisJ (148.48 $\left.\mathrm{ng} \mathrm{g}^{-1} \mathrm{fw}\right)$ were found in higher levels in the mature embryonic tissues to facilitate quicker germination in this recalcitrant seed. Seeds exhibited $\mathrm{GA}_{4} / \mathrm{ABA}$ antagonism with elevated $\mathrm{GA}_{4}$ levels and lower ABA levels. The stress-induced $S A$ was found in exceptionally high quantities in the embryonic tissues not reported elsewhere in other orthodox and recalcitrant seeds. 
cisJ was the predominant jasmonate, found to increase in the embryonic tissues during all stages of development. The brassinosteroid, epiBL was also found in significant levels in this recalcitrant seed.

\section{ACKNOWLEDGEMENT}

We gratefully acknowledge the University Grants Commission, New Delhi, for providing financial support for the successful completion of the work (20/12/2015(ii) EU$\mathrm{V})$, as well as the Indian Institute of Horticulture Research (ICAR), Bengaluru, Karnataka, for providing the LC-MS/MS facility for phytohormonal profiling.

\section{REFERENCES}

Ali-Rachedi, S., Bouinot, D., Wagner, M. H., Bonnet, M., Sotta, B., Grappin, P., Jullien, M.(2004). Changes in endogenous abscisic acid levels during dormancy release and maintenance of mature seeds: studies with the Cape Verde Islands ecotype, the dormant model of Arabidopsis thaliana. Planta. 219(3): 479-88. Doi: 10.1007/s00425-004-1251-4.

Alonso-Ramirez., A., Rodriguez, D., Reyes, D., Jimenez., J.A., Nicolas, G., lopez- Climent, M., Gomez-Cadenas, A., Nicolas, C., (2009). Evidence for a role of Gibberellins in salicylic acid-Modulated early plant responses to arabidopsis seeds. Plant physiology. 150(3): 1335-1344. Doi: $10.1104 / p p .109 .139352$.

Browse, J. and Howe, G.A. (2008). Update on jasmonate signaling: New weapons and rapid response against insect attack. Plant Physiolo. 146: 832-838.

Brodersen, P., Malinovsky, F.G., Hematy, K., Mari-Anne, N., Mundy, J. (2005). The role of salicyclic acid in the induction of cell death in arabidopsis acd11. Plant Physiology.138(2): 1037-1045. DOI: 10.1104/pp.105.059303.

Clouse, S.D. and Sasse, J.M. (1998). Brassinosteroids: Essential regulators of plant growth and development. Annu Rev Plant Physiol Plant Mol. Biol. 49: 427-451.

Farrant, J.M., Pammenter, N.W., Cutting, J.G.M., Berjak, P. (1993). The role of plant growth regulators in the development and germination of the desiccation-sensitive seeds of Avicennia marina. Seed Sci. Res. 3: 55-63.

Fukunda, H. (2004). Signals that control plant vascular cell differentiation. Nat. Rev. Mol. Cell Bio. 5: 379-391.

Gayatri, G.P., Ajith Kumar, K.G., Nair, P.S. and Pillai, M.S. (2021). GA/ABA antagonism in the physiology of seed germination in the recalcitrant and vulnerable tree Vateria indica $L$. Indian Journal of Agricultural Research. DOI: 10.18805/ IJARe.A-5729.

Gfeller, A., Liechi, R., Farmer, E.E. (2010). Arabidopsis jasmonate signaling pathway. Sci. Signal.3. doi:http://dx.doi.org/ 10.1126/scisignal. $3109 \mathrm{~cm} 4$.

Greller, A.M., Mohanan, N., Balasubramanyan, K. and Wijestmdara, D.S.A. (1999). Composition of forests at the Tropical Botanic Garden and Research Institute, Palode and comparisons with some forests of adjacent areas, Kallar and Ponmudi (Trivandrum District, Kerala, India). J. South Asian Nat. Hist. 2: 165-182.

India Meteorological Department. (2020). Climatological Tables of Observatories in India (2020). New Delhi.
IUCN Red List of Threatened Species (2019): e.T49487196A1458 21979) https://dx.doi.org/10.2305/IUCN.UK.2019-2.RLTS. T49487196A145821979.en.

Lorenzi, R., Vernieri, P. and Ceccarelli, N. (1988). Cytokinins in endosperm of Sechium edule SW. Seeds. Journal of Plant Physiology. 133: 310-325.

Mariana Rivas-San Vicente., Plasencia, J. (2011). Salicyclic acid beyond defense: its role in plant growth and development, Journal of Experimental Botany. 62(10): 3321-3338. doi.org/10.1093/jxb/err031.

Mussig, C. (2005). Brassinosteroid-Promoted Growth. Plant Biology. 7: 110-117. doi.org/10.1055/s-2005-837493.

Mustenko, L.I., Berestetsky, V.A., Vendenicheva, N.P., et al. (1995). Phytohormones and structure of cells of Acer saccharinum seed embryo. Biol. Plant. 37: 553-59.10.100/BF02908837.

Nair, P.S., Kumar, K.G.A., G.P.G. et al. (2020). Recalcitrant behavior of seeds of Syzygium cumini (L.) skeels during embryogeny and natural desiccation. Plant Physiol. Rep: 25: 426-131. 10.1007/s40502020-00528-2.

Nakagawara, S., Goto, T., Nara, M., Ozawa, Y., Hotta, K. and Arata, Y. (1998). Spectroscopic characterization and the $\mathrm{pH}$ dependence of the bactericidal activity of the aqueous chlorine solution. Anal. Sci. 14: 691-698

Nayar, T.S., Koshy, K.C., Sathish Kumar, C., Mohanan, N. and Mukuntha Kumar, S. (1986). Flora of the Tropical Botanic Garden, Palode. Tropical Botanic Garden and Research Institute, Trivandrum, xii $+144 \mathrm{pp}$.

Pan, X., Welti, R. and Wang, X. (2008). Simultaneous quantification of major phytohormones and related compounds in crude plant extracts by liquid chromatography-electrospray tandem mass spectrometry. Phytochem. 69(8): 1773-1781.

Pharis and King. (1985) Gibberellins and Reproductive Development in Seed Plants. Annual Review of Plant Physiology. 36(1): 517-568. doi: 10.1146/annurev.pp.36.060185.002505.

Rajjou, L., Belghazi, M., Huguet, R., Robin, C., Moreau, A., Job, C., Job, D. (2006). Proteomic investigation of the effect of salicylic acid on Arabidopsis seed germination and establishment of early defense mechanisms. Plant Physiology. 141: 910-923.

Reinbothe, C., Springer, A., Samol, I. and Reinbothe, S. (2009). Plant oxylipins: role of jasmonic acid during programmed cell death, defense and leaf senescence. The FEBS Journal. 276: 4666-4681. https://doi.org/10.1111/j.17424658.2009.07193.x.

Reinecke, D.M., Bandurski, R.S. (1987). Auxin Biosynthesis and Metabolism In: Plant Hormones and their Role in Plant Growth and Development. [Davies PT (eds)]. Springer, Dordrecht. http://doi.org/10.1007/978-94-009-3585-3_3.

Romero-Rodríguez, M.C., Archidona-Yuste, A., Abril, N., Gil-Serrano, A.M., Meijón, M. and Jorrín-Novo, J.V. (2018). Germination and Early Seedling Development in Quercus ilex Recalcitrant and Non-dormant Seeds: Targeted Transcriptional, Hormonal and Sugar Analysis. Front. Plant Sci. 9:1508. 10.3389/fpls.2018.01508.

Swami, S.B. and Kalse, S.B. (2020). Bioactive compounds in Jamun Syzygium cumini (L) Skeels. The Pharma Journal. 9(11): 161-167.

Soh, W.K. and Parnell, J.A.N. (2015). A revision of Syzygium Gaertn. (Myrtaceae) in Indochina (Cambodia, Laos and Vietnam). Adansonia. 37: 179-275. 
Soh, W.K. (2017). Taxonomy of Syzygium. In: The Genus Syzygium: Syzygium cumini and Other Underutilized Species. In: [Nair, K.N. (Ed.)] CRC Press, New York (ISBN 9781482 249729).

Valpuesta, V., Quesada, M.A., Sanchez-Roldan, C. et al. (1989). Changes in indole -3-acetic acid oxidase and peroxidase isoenzymes in the seeds of developing peach fruits. $\mathrm{J}$. Plant Growth Regul. 8: 255-261.10.1007/BF02021818.

Van Staden, J., Davey, J.E. and Brown, N.A.C. (1982). Cytokinins in seed development and germination. in Khan, A.A. (Ed.) The physiology and biochemistry of seed development, dormancy and germination.Amsterdam, New York, Oxford, Elsevier Biochemical Press. Pp 137-156.

Vishal, B. and Kumar, P.P. (2018). Regulation of Seed Germination and Abiotic Stresses by Gibberellins and Abscisic Acid. Front. Plant Sci. 9: 838. 10.3389/fpls.2018.00838.
Wang, Y., Li, I., Ye, T., Zhao, S., Liu, Z., Feng, Y.Q., et al. (2011). Cytokinin antagonizes ABA suppression to seed germination of Arabidopsis by downregulating $A B 15$ expression. Plant J. 68: 249-261. doi:10.1111/j¹365-313X.2011.04683.x.

Wijers, D. and Jurgens, G. (2005). Auxin and embryo axis formation the ends in sight? Current Opinions Plant Biol. 8: 32-7.

Xie, Z., Zhang, Z.L., Hanzlik, S., Cook, E., Shen, Q.J. (2007). Salicylic acid inhibits the gibberellin-induced alphaamylase expression and seed germination via a pathway involving an abscisic-acid inducible WRKY gene. Plant Molecular Biology. 64: 293-303.

Zhang, Y., Yang, C., Li, Y., Zheng, N., Chen, H., Zhao, Q. et al. (2007). SDIR1 is a RING finger E3 ligase that positively regulates stress-responsive abscisic acid signaling in Arabidopsis. Plant Cell. 19: 1912-1929.10.1105/ tpc.106.048488. 